\title{
JOGHATÓSÁG ÉS ÁLLAMI IMMUNITÁS A KULTURÁLIS JAVAK VISSZASZOLGÁLTATÁSÁVAL KAPCSOLATOS PEREKBEN
}

https://doi.org/10.51783/ajt.2021.1.05

\begin{abstract}
A kulturális javak visszaszolgáltatásának komplex kérdésköre az utóbbi évtizedekben a tudományos vizsgálódás homlokterébe került. Ennek oka egyrészről, hogy az eredetkutatást elősegítő dokumentumok hozzáférhetövé válásával jelentősen megnőtt a restitúciós perek száma, másrészt - ezzel összefüggésben - az egyre szélesebb körben szorgalmazott szabályozási igényre válaszként, új nemzetközi és speciális belső jogforrások születtek. A jogellenesen elvett kulturális javak visszaszerzéséért folyó - jellemző módon nemzetközi elemet tartalmazó - eljárások kimenetele gyakran a nemzetközi magánjogi szabályokon múlik. A kolliziós jog - mely a jogvitára alkalmazandó jog kijelölésére hivatott - meghatározó szerepe magától értetődő, ha figyelembe vesszük az egyes államok jogrendszerének legeltérőbb dologi jogi megoldásait, illetve az egységes nemzetközi in rem jogforrások hiányát. Az eljárásjogi rendelkezések jelentősége talán kevésbé szembeötlö, mégis megkérdöjelezhetetlen: jelen írás ennek megfelelöen a már rögtön az eljárás kezdetén felmerülö kérdések elemzésére hivatott, ismertetve a speciális joghatósági szabályozást beiktató újabb normákat, illetve az eljárás alanyait, központban a sajátos státuszú állammal.
\end{abstract}

\section{BEVEZETÉS}

A kulturális javak visszaszolgáltatását célzó eljárásokat speciális jellemzőkkel írhatjuk le. E perekben egyrészt az érdekek differenciált köre jelenik meg: attól függően, hogy az érintett tárgy milyen módon került ki eredeti tulajdonosa birtokából, a jogvitában érintettek lehetnek szent tárgyukért harcoló vallási csoportok, identitásuk meghatározó elemét visszakapni vágyó államok vagy akár családi örökségükért küzdő magánszemélyek. Másrészt, mivel a mütárgyak értékesek és könnyen mozgathatók, ${ }^{1}$

* Tudományos segédmunkatárs, Társadalomtudományi Kutatóközpont Jogtudományi Intézet, 1097 Budapest, Tóth Kálmán u. 4. E-mail: vadasz.vanda@tk.hu.

1 A művészeti és kulturális iparág hozzávetőlegesen évi 698 milliárd dollárt mozgat meg. Ashley FLYNN: „Lending Loot: The Cost of Cultural Exchange under the Immunity from Seizure Act” Hofstra Law Review 2016/4. 1306. A jogellenesen elvett kulturális javakat általában a származási helytől messzire transzportálva igyekeznek értékesíteni, az eredet illegális voltát kendőzendő. A mára szokványosnak mondható jelenség elleni harc herkulesi feladat, melyben - a kulturális javakat speciálisan szabályozó terület hiányában - elengedhetetlen az érintett jogágak (nemzetközi magánjog, nemzetközi közjog, polgári jog, közigazgatási jog stb.) rezonálása. Anne-Marie CARSTENS - Elizabeth 
a visszaszerzésük érdekében indított eljárások igen gyakran tartalmaznak nemzetközi elemet. Az ítélkező fórumnak így, a nemritkán etikailag és politikailag is érzékeny kérdésekkel tủzdelt jogvitát a nemzetközi magánjog szabályait alkalmazva kell feloldania.

Egy restitúciós eljárás megindulásakor a fórumnak mindenekelőtt joghatóságáról, a nemzetközi magánjogi tényállás első eljárásjogi feltételének meglétéről kell határoznia. Jelen írás célja, hogy feltérképezze, eme első vetület a kulturális javak viszszaszolgáltatását érintő jogviták esetén milyen sajátosságokat mutat. Ennek körében bemutatjuk a közelmúltban megalkotott európai uniós és hazai normákat. Az eljárás megindulása kapcsán továbbá kiemelt figyelmet fordítunk az alanyok speciális körére, az állam restitúciós perekben betöltött szerepére - így az állami immunitás által felvetett problémákra.

\section{A JOGHATÓSÁG MEGÁLLAPÍTÁSA}

A kulturális jószágot bíróság előtt visszakövetelő fél első lépése azon kompetens fórum kiválasztása, amely előtt a restitúciós eljárást megindíthatja. ${ }^{2}$ Minden állam rendelkezik olyan szabályrendszerrel, amely meghatározza, mely esetekben indulhat meg az eljárás belső fóruma előtt. ${ }^{3} \mathrm{~A}$ belföldi szabályozás mellett nemritkán nemzetek feletti források is rendezik a kérdést.

Ha a magyar fórumnak kell saját joghatóságáról dönteni egy kulturális javak viszszaszolgáltatásával kapcsolatos eljárásban, szükséges áttekintenie a jelenleg érvényben lévő, többcsatornás jogforrási rendszert. Az eset egyedi sajátosságaitól függően alkalmazható nemzetközi egyezmény, ${ }^{4}$ uniós eredetủ jogszabály, ${ }^{5}$ illetve belső joghatósági norma.

VARNER: „Intersections in International Cultural Heritage Law. Past, Present, Future” in AnneMarie CARSTENS - Elizabeth VARNER (szerk.): Intersections in International Cultural Heritage Law. (Oxford: Oxford University Press 2020) 1. https://doi.org/10.1093/oso/9780198846291.003.0001.

2 Nemzetközi magánjogi szempontból nézve a joghatósági szabályok a nemzeti jogi fennhatóság határait jelölik ki. „Ahhoz, hogy a [bíróság] perben, vagy egyéb ügyben eljárhasson, azonkívül, hogy hatáskörrel és illetékességgel kell bírnia, szükséges az is, hogy a perre vagy egyéb hatóságai eljárására joghatósága (jurisdictioja) legyen.” SzÁszy István: Nemzetközi magánjog. Előadások a Budapesti Pázmány Péter Tudományegyetem jogi karán 1949/1950. iskolai év folyamán. (Budapest: MEFESZ Jogászkör, Jegyzetosztály 1950) 33.

3 Ahhoz, hogy az adott állam fórumának joghatósága fennálljon, szükséges, hogy az ügynek a belföldhöz füződő kapcsolata kellőképpen szoros legyen. Ez a kapcsolat számos formában megmutatkozhat: többek között az alperes kapcsolatában a fórum államával, a jogvita tárgyának elhelyezkedésében, az eljárásra okot adó körülmények helyében, a felek fórumválasztásában.

4 Különleges szabályt tartalmaz, így érdemes kitérni a 2001. évi XXVIII. törvénnyel jogrendünkbe ültetett, a lopott vagy jogellenesen külföldre vitt kulturális javak nemzetközi visszaadásáról 1995-ös UNIDROIT Egyezményre, ugyanis a számos, e javak védelme tárgyában született nemzetközi egyezmény közül egyedül ebben találhatók a kulturális javak visszaszolgáltatása tárgyában indított magánjogi keresetre vonatkozó (puha jogi) rendelkezések. Az Egyezmény ugyanis 8. cikkében („[...] kérelmet az Egyezményben részes azon állam bírósága vagy más illetékes hatósága elé lehet terjeszteni, ahol a kulturális tárgy található, az Egyezményben részes államok érvényes jogszabályai szerint egyébként erre hatáskörrel rendelkező bíróságok vagy más illetékes hatóságok mellett.") a kulturális tárgy fekvési helyére alapított kiegészítő joghatósági okot hoz létre a részes államok vonatkozásában.

5 Kimerítően sorolja: Gomвоs Katalin: „A Brüsszel IA rendelet és a készülő nemzetközi magánjogi törvény egymáshoz való viszonya” in BERKE Barna - NEMEssáNYI Zoltán (szerk.): Az új nemzetközi 
Utóbbiakat illetően a 2010-es évek második fele lényeges változásokat hozott, 2015-ben ugyanis hatályba lépett a polgári és kereskedelmi ügyekben a joghatóságról, valamint a határozatok elismeréséről és végrehajtásáról 1215/2012/EU rendelet (a továbbiakban: Brüsszel I. bis rendelet), ${ }^{6}$ mely az elődjétől eltérően különleges szabályt tartalmaz a kulturális javakkal kapcsolatos ügyekre. Szintén e javakra alkalmazandó, dologi jogokra szabott normát ültetett be a 2018-ban hatályba lépő 2017. évi XXVIII. törvény a nemzetközi magánjogról (Kódex).

\subsection{A BRÜSSZEL I. BIS RENDELET KÜLÖNÖS SZABÁLYA}

Az utóbbi években a kulturális javak védelme mint absztrakt cél az EU jogalkotási tevékenységében egyre hangsúlyosabban jelenik meg. ${ }^{7}$ Ennek egyik megnyilvánulásaként kezelendő a módosult - mind az európai uniós, ${ }^{8}$ mind a hazai jogrendben kiemelt helyet elfoglaló ${ }^{9}$ - Brüsszel I. bis rendelet által beiktatott speciális joghatósági ok is.

Az általános felállás a kulturális javak visszaszolgáltatását célzó jogvitákban, hogy a visszakapni kívánt műtárgy az alperes birtokában van. Ebben az esetben pedig az actor sequitur forum rei elve tökéletesen alkalmas a joghatóság kijelölésére, vagyis a Brüsszel I. bis rendelet általános joghatósági szabályát hívják fel: valamely tagállamban lakóhellyel, székhellyel rendelkező személy az adott tagállam bírósága előtt perbe vonható. ${ }^{10} \mathrm{Ez}$ a joghatósági ok akkor kevéssé hatékony, ha a felperes számára

magánjogi törvény alapjai. Kodifikációs elötanulmányok (Budapest: HVG-Orac 2016) 173-175.

6 Felváltotta $a$ Tanács 44/2001/EK rendeletét a polgári és kereskedelmi ügyekben a joghatóságról, valamint a határozatok elismeréséről és végrehajtásáról (Brüsszel I. rendelet).

7 Ezt tanúsítja a 2014/60/EU irányelv az Európai Parlament és a Tanács 2014/60/EU irányelve a tagállamok területéröl jogellenesen kivitt kulturális javak visszaszolgáltatásáról és az 1024/2012/ EU rendelet módositásáról vagy az Európai Parlament és a Tanács 2019/880 rendelete a kulturális javak bejuttatásáról és behozataláról. Az EU kulturális örökségvédelmi szabályairól átfogóan ld.: Michele GRAZIADEI - Barbara PASA: „The Single European Market and Cultural Heritage: The Protection of National Treasures in Europe" in Andrzej JAKUBOwsKI - Kristin HAUSLER - Francesca FioRentini (szerk.): Cultural Heritage in the European Union. A Critical Inquiry into Law and Policy (Leiden: Brill 2019) 79-112. https://doi.org/10.1163/9789004365346_006.

8 „[A] Brüsszel I. rendelet ugyanis az EU polgári eljárásjogának zászlóshajója, amerre fordul, abba az irányba megy a többi vonatkozó EU-s norma is.” OszTovirs András: „A Brüsszel I. rendelet reformja" in Osztovits András (szerk.): Acta Caroliensia Conventorum Scientiarum IuridicoPoliticarum II. A Brüsszel I. rendelet reformja. (Budapest: Károli Gáspár Református Egyetem Állam- és Jogtudományi Kara, 2012) 7. A joghatóságot, elismerést és végrehajtást szabályozó „brüsszeli rezsim” a legrégebbi és legtöbbet használt uniós eszköz a nemzetközi magánjog területén. [Xandra Kramer - Alina OnTANU - Michiel de RooIs: „The application of Brussels I (Recast) in the legal practice of EU Member States. Synthesis Report." Asser Institute, 2019. 1. www.asser.nV media/5018/m-5797-ec-justice-the-application-of-brussels-1-09-outputs-synthesis-report.pdf

9 Európai uniós tagságunk kezdete óta a nemzetközi magánjogi ügyek jelentős része uniós viszonylatban merül fel, melyek esetén a rendelet szabályai hívandók fel. MÁdL Ferenc - VÉKÁs Lajos: Nemzetközi magánjog és nemzetközi gazdasági kapcsolatok joga (Budapest: ELTE Eötvös Kiadó 2018) 518.

${ }^{10}$ Brüsszel I. bis rendelet 4. cikk. Megjegyzendő, hogy „az Európai Bíróság értelmező gyakorlata szerint általános joghatósági szabályait akkor is alkalmazni kell a Magyarországon lakóhellyel, székhely- 
sem az alperes személye, sem a lakóhelye nem ismert, illetve, ha a tárgy egy harmadik tagállamban fekszik. Ez az eshetőség sem ritka, ha arra gondolunk, milyen sűrün szállítják a tárgyakat más államokba - például aukciós célokból.

Ilyen körülmények merültek fel példának okáért a Heylshof-ügyben. A tényállás szerint a svájci megbízó egy, a wormsi Heylshof Múzeumból ellopott festményt kívánt elárverezni a bécsi Dorotheum Aukciósház által, amikor egy német alapítvány bejelentette a képpel kapcsolatos tulajdoni igényét. Mindkét fél a Dorotheumtól kérte állítólagos tulajdona visszaszolgáltatását. Az aukciósház a bécsi helyi bíróságnál helyezte őrizetbe a képet azzal, hogy az határozzon a két fél tulajdoni igényével kapcsolatban. Csakhogy ahhoz, hogy a kép a bíróság őrizetéből kikerüljön, az osztrák szabályok alapján szükséges a birtokos és az állítólagos eredeti tulajdonos közti eljárás megindítása, és a felek erről történő megállapodása. A svájci fél a hatályban lévő Brüsszel I. rendelet alapján a német fél ellen az osztrák bíróság előtt nem indíthatott pert, a német fél részére pedig a Luganói Egyezmény nem biztosított hasonló lehetőséget. Annak ellenére tehát, hogy a tárgy az osztrák bíróság őrizetében volt, a felek nem indíthatták meg itt az eljárást, megfelelő joghatósági ok hiányában. ${ }^{11}$

Hasonló helyzetek kiküszöbölése érdekében állapít meg a rendelet ún. vagylagos joghatósági okokat, melyek célja, hogy az eljárás lefolytatható legyen abban a társadalmi, gazdasági és jogi környezetben, amelyhez azt szoros kapcsolat füzi, ezáltal téve hatékonnyá az igazságszolgáltatás menetét. ${ }^{12}$ A kulturális javak visszaszolgáltatását célzó eljárások kapcsán felhívható, új vagylagos joghatósági ok a rendelet 7. cikk 4. pontjában kapott helyet, és a következőképpen szól: „[v]alamely tagállamban lakóhellyel rendelkező személy más tagállamban az alábbiak szerint perelhető: [...] a tagállam területéről jogellenesen kiszállított kulturális tárgyak visszaszolgáltatásáról szóló 93/7/EGK irányelv 1. cikkének (1) pontjában meghatározott kulturális tárgyak visszaszolgáltatására irányuló, tulajdonjogon alapuló polgári jogi kereset esetén annak a helynek a bírósága előtt, ahol a kulturális tárgy a bíróság felhívásának idején fellelhető".

Ennek megfelelően a tárgyát visszaszerezni kívánó felperes választása szerint eljárást indíthat a tárgy fekvési helye szerinti állam fóruma előtt is. A fekvési hely kapcsolóelvének alkalmazása a gyakorlatban általában problémamentes, a bíróságok azonban ebben a körben is szembesülhetnek kihívást jelentő esetekkel. Dologösszesség esetén például, ha egy gyüjtemény darabjai különböző államok-

lyel rendelkező alperesekre, ha az ügy releváns nemzetközi eleme nem egy másik EU-tagállamhoz, hanem harmadik államhoz kötődik.” Goмвos Katalin: „A joghatóság egyes kérdései a nemzetközi magánjogban” Pro Publico Bono - Magyar Közigazgatás, 2019/2. 90. https://doi.org/10.32575/ ppb.2019.2.5.

11 Matthias Weller: „Study on the European added value of legislative action on cross-border restitution claims of works of art and cultural goods looted in armed conflicts and wars with special regard to aspects of private law, private international law and civil procedure" in: Matthias WeLLER (SZERK.): Rethinking EU Cultural Property Law: Towards Private Enforcement (Baden-Baden: Nomos Verlag 2018) 39-40. https://doi.org/10.5771/9783845290140-13.

12 „A szoros kapcsolat megléte jogbiztonságot nyújt és elkerüli azt, hogy az alperes ellen egy olyan tagállam bíróságán indíthassanak eljárást, amelyre észszerűen nem számíthatott.” Brüsszel I. bis (16) második mondata. 
ban találhatók, a bíróságnak az adott eset körülményeit megvizsgálva kell döntenie arról, hogy mely fórumhoz kapcsolódik szorosabban az ügy. Esetleg ha a mütárgy úton lévő dolognak (res in transitu) is minősül, érdemes a 7. cikk 1. bekezdés b) pont első francia bekezdésére figyelemmel lenni, mely ingó dolog értékesítése esetén a vitatott kötelezettség teljesítésének helyeként azt a területet jelöli ki, „,ahol a szerződés alapján az adott dolgot leszállították, vagy le kellett volna szállítani”. Analógiát alkalmazva ebben az esetben a rendeltetési állam fóruma jogosult eljárni. ${ }^{13} \mathrm{~A}$ kapcsolóelv alkalmazása szempontjából mérvadó időpont meghatározása igen fontos, tekintettel a kulturális javak már említett könnyü mozgathatóságára: a normaszöveg a bíróság felhívásának idejéről szól, mely az eljárás megindításának időpontja, az iratok bírósághoz történő benyújtásának ideje. ${ }^{14}$

A kulturális javakkal kapcsolatos követelésekkel, de általánosságban a dologi jogok érvényesítésével összefüggően a fekvés helyén biztosított joghatóságról összességében elmondható, hogy számos előnnyel kecsegtet, hiszen ebben az esetben az eljárás helye ott van, ahol a szükséges bizonyítékok könnyebben, gyorsabban elérhetők. Ezen felül, mivel annak az országnak a jogrendje, ahol az ingó fizikailag van, úgymond „természetes” elsőbbséget élvez az ottani jogok érvényesítése tekintetében, a döntés végrehajtása is biztosabbnak tűnik. ${ }^{15} \mathrm{~A}$ szabályhely alkalmazásával kapcsolatban azonban megjegyzendő, hogy a per tárgyának minősítése - ti., hogy a 93/7/ EGK irányelv ${ }^{16}$ által meghatározott kulturális javak körébe tartozó ingóról van-e szó -, a megkeresett fórum feladata. Márpedig, mint arra Matthias Weller felhívja a figyelmet, ${ }^{17}$ amikor a rendelet a 93/7/EGK irányelvre utalva határozza meg a kulturális javak körét, azért nem nevezhető szerencsés megoldásnak ${ }^{18}$ mert ezt az irányelvet a kulturális javak egy tágabban meghatározott fogalmával dolgozó 2014/60/

13 Pietro Franzina: „The Proposed New Rule of Special Jurisdiction Regarding Rights in rem in Moveable Property: A Good Option for a Reformed Brussels I Regulation?” Diritto del commercio internazionale, 2011/3. 10-12.

14 Annak megakadályozására, hogy a tárgy vándoroljon a „joghatóságok” közt, a Brüsszel I. bis rendelet 35. cikke biztosít hatékony eszközt, mely a következőképpen szól: „[v]alamely tagállam bíróságainál az adott tagállam joga alapján rendelkezésre álló ideiglenes intézkedések - beleértve a biztosítási intézkedéseket is - még akkor is kérelmezhetőek, ha az ügy érdemére vonatkozóan más tagállam bírósága rendelkezik joghatósággal."

${ }^{15}$ Lásd Franzina (13. lj.) 2-3.

${ }^{16}$ A Tanács 93/7/EGK irányelve a tagállam területéről jogellenesen kiszállított kulturális tárgyak visszaszolgáltatásáról. A fogalommeghatározásokat az 1. cikk tartalmazza.

17 Lásd Weller (11. lj.) 41.

18 A rendelet előkészítése során felmerült - sőt, a végső módosításcsomagban is az szerepelt -, hogy az ingókkal kapcsolatos dologi jogi követeléseket az ingó dolog fekvésének helyén is érvényesíteni lehessen. [European Commission's Proposal for a Regulation of the European Parliament and of the Council on jurisdiction and the recognition and enforcement of judgments in civil and commercial matters (Recast) 2010. Article 5. point 3.] A rendelet végső formájában kizárólag a kulturális javakkal kapcsolatban fogalmaz meg speciális joghatósági szabályt, ám egy általános in rem követelésekre szabott norma kialakítását a kulturális javakra vonatkozó uniós szabályozás elemzői máig szorgalmazzák. Így: Christian SALM: Cross-border restitution claims of looted works of art and cultural goods. European Parliamentary Research Service, 2017. 13. (https://www.europarl.europa.eu), Tanja DomEJ: „Die Neufassung der EuGVVO: Quantensprünge im europäischen Zivilprozessrecht” Rabels Zeitschrift für ausländisches und internationales Privatrecht, 2014/3. 528. https://doi. org/10.1628/003372514X682685. 
EU rendelet időközben felváltotta. ${ }^{19}$ Ebben a körben kívánatos lenne, ha az alkalmazást illetően további eligazítást kapnának a nemzeti bíróságok. Ezen túl számolni kell azzal, hogy a 7. cikk 4. pont is, mint minden vagylagos joghatósági ok, megteremti a forum shopping lehetőségét. Ennek kiküszöbölése azonban nem az eljárásjogi, hanem inkább a kollíziós, illetve anyagi jogi szabályozás szintjén képzelhető el.

A kapcsolatszegény joghatósági okok problematikája is felvetődhet az új szabályt vizsgálva. A rendelet elődei ugyanis - az 1968-as Brüsszeli Egyezmény, ${ }^{20}$ majd a Brüsszel I. rendelet I. mellékletében - tagállamonként listába szedte az exorbitánsnak minősülő szabályokat. Magyarország tekintetében például a vagyon fekvésére alapított joghatósági okot tartotta ilyennek, mely, a rei sitae joghatósági okokkal egyetemben tradicionálisan exorbitánsnak minősül. ${ }^{21} \mathrm{~A}$ joghatóságot rendező egységes jogforrások egyik fő célja márpedig az egyes tagállamok hasonló joghatósági szabályaival ${ }^{22}$ szembeni védelem biztosítása, ${ }^{23}$ annak elkerülése, hogy a felperes a kapcsolatszegény joghatósági szabály kihasználásával saját fóruma elé citálhassa a tagállami lakóhellyel rendelkező alpereseket. ${ }^{24,25}$

${ }^{19}$ Salm felhívja a figyelmet arra, hogy a különös joghatósági ok normaszövegbe emelésével problémaként jelentkezik a Luganói Egyezménnyel létrehozni kívánt összhang hiánya is. Az Egyezményben ugyanis nincsen hasonló joghatósági szabály, igy a részes államában telephellyel vagy lakóhellyel rendelkezö fél csak az általános joghatósági ok alapján perelhetö. Lásd SALM (18. lj.) 10-11.

${ }^{20}$ Egyezmény a polgári és kereskedelmi ügyekben a joghatóságról, valamint a határozatok elismeréséröl és végrehajtásáról.

${ }^{21}$ Lorna E. GILLIES: „The contribution of jurisdiction as a technique of demand side regulation in claims for the recovery of cultural objects" Journal of Private International Law, 2015/2. 304. https:// doi.org/10.1080/17441048.2015.1068003.

${ }^{22}$ Az exorbitáns joghatósági szabályok olyan normák, melyek az egyes jogrendszereken belül érvényes szabályként müködnek, ennek ellenére az alperest mégis igazságtalan helyzetbe hozzák, tekintettel arra, hogy - főleg területi vonatkozású joghatósági szabályoknál - sem a szuverén, sem az eljárásban részes felek kapcsolódása a fórumhoz nem feltétele azok megállapításának. Kevin M. CLERMONT - John R. B. Palmer: „Exorbitant Jurisdiction” Maine Law Review 2006/2. 474.

${ }^{23}$ Osztovits András: „Joghatóság a Brüsszel-I-a rendelet alapján” in: VARGA István (szerk.): A polgári perrendtartás és a kapcsolódó jogszabályok kommentárja IIL/III. (Budapest: HVG-Orac, 2018) 2391-2455. Más joghatósági jogforrásokhoz való viszony.

${ }^{24}$ Általános tételként elmondhatjuk, hogy az exorbitáns joghatósági ok alapján történő eljárás az elismerés és végrehajtás folyamatában „üt vissza”. Az elismerés és végrehajtás helye szerinti bíróság elött ugyanis az alperesek érvelhetnek azzal, hogy a határozatot hozó bíróságnak - nemzetközi jogi értelemben - nem volt joghatósága. Az EU tagállamai viszonylatában azonban ez a tétel nem igazolható, hiszen az elismerés és végrehajtás uniós szabályai kizárják az eredeti tagállami döntés felülvizsgálatát. NAGY Csongor István: Nemzetközi magánjog (Budapest: HVG-Orac, 2017) 189-190.

${ }^{25}$ Jó példáját adja a peres felek hasonló törekvésének azon ügy, melyben a magyarországi felperes az egyesült királyságbeli Christie's International PLC, valamint az amerikai Christie's Incorporation alperesek ellen indított, s amelyben a Fővárosi Ítélőtáblának kellett joghatóságáról döntenie. (Fővárosi Ítélötábla Pf. 21.326/2017/9.) Az ügy a Christie’s árverésén vásárolt festményekkel volt kapcsolatos, melyben a felperes tulajdonjogának megállapítását, valamint szerződésen kívül keletkezett kárának megtéritését kérte. A kárfelelősség alapjául azt jelölte meg, hogy az alperes a képeket ismeretlen helyre vitte, és jogellenesen magánál tartja, valamint a már megvásárolt műalkotásokat megkárosította. A felperes a Pesti Központi Kerületi Bíróság eljárásában eleinte a joghatóságot a Brüsszel I. rendelet 5. cikkének 3. bekezdésére alapította, mely a jogellenes károkozással, vagy azzal egy tekintet alá eső cselekménnyel vagy ilyen cselekményből fakadó igénnyel kapcsolatos ügyekben annak a bíróságnak ad eljárási képességet, amely államában a káresemény bekövetkezett vagy bekövetkezhet. A felperes ebben a körben a javítás költségére hivatkozott, melyet Magyarországon kell állnia. Mikor a bíróság 
Az európai jogalkotó részéről tehát perspektívaváltó lépése volt az új, kulturális javakra szabott területi alapú joghatósági ok beiktatása. A felvetett alkalmazási nehézségek kiküszöbölhetők akár a bíróságok - mind ez idáig visszafogott ${ }^{26}$ - jogértelmezési tevékenysége által, így a rendelet adekvát eszközt nyújthat a kulturális javakat érintő eljárások ideálisabb körülményeinek megteremtésére.

\subsection{A KÓDEX}

A Brüsszel I. bis rendeletben lefektetett különös joghatósági szabály alkalmazásához szükséges, hogy az alperes lakóhelye az EU tagállamának területén legyen. Ha a szabályhely felhívására szükség van, az is nyilvánvaló, hogy a tárgy az alperes lakóhelyétől különböző tagállamban fekszik. Szükséges számításba venni azt az esetet, amikor az alperes lakóhelye harmadik államban van. Ilyenkor a joghatósági kérdések tekintetében a tagállamok belső szabályozása érvényesül.

Az egyes országok nemzetközi eljárásjogot illető belső szabályozása gyakran fordít megkülönböztetett figyelmet a dologi jogokkal kapcsolatos igényekre. Anglia, Skócia és Wales vonatkozó szabályai saját bíróságaik számára kizárólagos joghatóságot biztosítanak az olyan eljárások felett, amelyek tárgyát dologi jogok képzik, az alperes lakóhelyétől függetlenül. ${ }^{27}$ Hasonló felfogás érvényesül Németországban: a polgári perrendtartás alapján ugyanis az ingó dolog fekvésének helyén is indítható eljárás, akkor is, ha az alperes nem rendelkezik Németországban lakóhellyel, székhellyel. ${ }^{28}$ A svájci nemzetközi magánjogi törvény ${ }^{29} 98$. cikke tartalmazza az ingók tulajdonjogával kapcsolatos követelésekre vonatkozó joghatósági szabályokat. Eszerint az ilyen ügyekre az alperes lakóhelye, illetve székhelye, ezek hiányában pedig szokásos tartózkodási helye szerinti fórum rendelkezik joghatósággal. Párhuzamos joghatósági okként jelenik meg az ingó fekvésének helye. ${ }^{30}$

ezt az érvelést elutasította (Pesti Központi Kerületi Bíróság 27.G.303.075/2010.), a Balassagyarmati Törvényszékhez folyamodott jogorvoslatért, s beadványában a magyar fórum joghatóságának megállapítását a rendelet fogyasztók védelmére létrehozott különös joghatósági szabálya alapján kérte (Balassagyarmati Törvényszék P. 20.187/2017/13.). Az ügy szempontjából a Törvényszék, majd végül a Fővárosi İtélőtábla is irrelevánsnak találta az előbbi kitételt, s elutasította joghatósága megállapítását. Az Ítélőtábla érvelésében kifejtette, hogy „[a] joghatóság vizsgálata során a felperes által érvényesített jog és az annak alapján előterjesztett keresetből kell kiindulni. Annak vizsgálatára egyetlen jogszabály sem kötelezi az alperest, hogy a felperes által különböző jogcímeken előterjesztett kereseti kérelmeken túl a tényállásból következő valamennyi esetlegesen felmerülő jogcímet vizsgálat tárgyává tegye annak érdekében, hogy a felperes igénye szerint a magyar bíróság joghatósága megállapíthatóvá váljon."

${ }^{26}$ Az Európai Unió Bíróságának, valamint a rendelet tagállami alkalmazását vizsgáló, Európai Bizottság által finanszírozott projekt esetjogi keresője (asser.nVbrusselsibis) a kézirat lezárásának időpontjában nem hoz találatot a kérdéses pontra.

${ }^{27}$ Christa Roodt: Private International Law, Art and Cultural Heritage (Cheltenham: Edward Elgar Publishing 2015) 169. https://doi.org/10.4337/9781781002162.

28 Zivilprozessordnung in der Fassung der Bekanntmachung vom 5. Dezember 2005, § 23.

${ }^{29}$ Federal Act on Private International Law of 18 December 1987 (CPIL).

${ }^{30}$ CPIL 98. § (2) Érdekesség, hogy a CPIL 98a cikke külön joghatósági rendelkezést tartalmaz azon eljárásokra, amelyeket egy másik állam indít annak területéről jogellenesen kivitt kulturális javak 
Immáron hazai szabályozásunk is tartalmaz az ingó dolgokkal kapcsolatos speciális kiegészítő joghatósági okot. A Kódex 95. § alapján „[m]agyar bíróság eljárhat olyan eljárásban, amelynek tárgya az eljárás megindulásának időpontjában belföldön található ingó dolgon fennálló dologi jog." A beiktatott új rendelkezés indoka a Kódex megalkotásának azon vezérelve, hogy lehetőség szerint kövesse a releváns uniós rendeletek - jelen esetben a Brüsszel I. bis rendelet - szabályait. ${ }^{31}$ A normaszöveg ugyan „ingó dolgot” említ, a rendelkezés megalkotásának célja kifejezetten a kulturális javak és a tulajdonos birtokából jogellenesen kikerült dolgokon fennálló tulajdonjogi igényre megállapított új kollíziós szabályokhoz ${ }^{32}$ igazodó szakasz megalkotása volt. ${ }^{33}$

Ha tehát a kulturális jószág fizikailag Magyarországon található, akár uniós tagállamban lakóhellyel rendelkező, akár harmadik állambeli alperessel szemben eljárás indulhat a magyar fórumon.

\section{AZ ELJÁRÁSOK ALANYAI ÉS AZ ÁLLAMI IMMUNITÁS}

A kulturális javak visszaszolgáltatásával kapcsolatos perekben félként a jogalanyok legkülönbözőbb csoportjai vesznek részt. A múzeumok például, melyek a mủtárgyak beszerzésére, megőrzésére, nyilvánosságnak történő bemutatására, illetve az azokkal kapcsolatos tudományos kutatások folytatására hivatottak, szerepükből adódóan gyakran jelennek meg az ilyen perekben, ${ }^{34}$ hasonlóképpen az aukciós házakhoz és a műtárgykereskedőkhöz. ${ }^{35}$ Az egyes mủtárgykereskedelemben érdekelt csoportok gyakran szerveződnek, ${ }^{36}$ melynek a jogviták rendezése terén számos pozitív hozadéka van. ${ }^{37}$ Az egyéni gyüjtők és mütárgytulajdonosok - gyakran örökösi pozíció-

visszaszolgáltatása céljából. Az eljárás ilyen esetben az alperes lakóhelyén, székhelyén, üzleti helyén vagy a jószág fekvési helyén eljárni jogosult bíróság előtt indítható.

31 VÉKÁs Lajos: „A »külföldi elem« a nemzetközi magánjogi tényállásban” Jogtudományi Közlöny 2019/10. 381.

32 A kollíziós szabályok elemzését ld. VADÁsz Vanda: „A kulturális javakkal kapcsolatos jogvitákra irányadó jog a magyar jogrendszerben” Külgazdaság Jogi Melléklete 2020/3-4.

${ }^{33}$ T/14237. számú törvényjavaslat a nemzetközi magánjogról, 2017. 89. o.

${ }^{34}$ Részletesen ld. Leila Amineddoleh: „The Role of Museums in the Trade of Black Market Cultural Heritage Property" Art Antiquity and Law 2013/3. 235.

35 Közös nevezőként funkcionál, hogy müködésükből eredően mindannyian a mütárgyak szabad kereskedelmében érdekeltek. (A javak hatalmas méreteket öltő árnyékpiaca azonban etikai megfontolások bevezetésére késztette őket - nívós dokumentumok az 1984-es Code of Practice for the Control of International Trading in Works of Art, vagy az újabb, 2015-ös, International Association of Dealers in Ancient Art gondozásában megjelent The Code of Ethics).

${ }^{36}$ A legfontosabbak az International Council for Monuments and Sites, az International Council of Museums (ICOM) és az International Law Association.

${ }^{37}$ Az ICOM 2011-ben a Szellemi Tulajdon Világszervezetével együttmüködve meditációs programot hozott létre a múzeumi szektor számára, egy tanzániai múzeumból ellopott és egy svájci múzeum által 1985-ben megszerzett Makonde-maszkkal kapcsolatos helyreállítási ügy hozadékaként. Evelien Campfens: „Alternative Dispute Resolution in Restitution Claims and the Binding Expert Opinion Procedure of the Dutch Restitutions Committee" in Valentina VAdi, Hildegard E.G.S. SCHNEIDER (szerk.): Art, Cultural Heritage and the Market Ethical and Legal Issues (Basel: Springer 2014) 79-80. https://doi.org/10.1007/978-3-642-45094-5_3. 
ban - szintén gyakori résztvevői a vizsgált eljárásoknak. ${ }^{38}$ Mindezen csoportokat tekintve azonban az, hogy a kulturális javak visszaszolgáltatását célzó eljárásokban peres félként jelenhetnek-e meg, jellemzően nem nevezhető neuralgikus pontnak. ${ }^{39}$

\subsection{AZ ÁLLAM SZEREPE A RESTITÚCIÓS PEREKBEN}

Számos kérdést vet fel azonban az állam visszaszolgáltatási perben félként történő (igen gyakori) ${ }^{40}$ részvétele. Köztudott ugyanis, amikor az állam megjelenik a nemzetközi porondon - akár peres félként egy nemzetközi jogvitában -, megkülönböztetett jogállást igényel magának. Ez a körülmény az állam szuverenitásából fakad. ${ }^{41}$ A joghatóság alóli mentesség - mint az állami immunitás egyik szegmense - a szuverenitás lényeges eleme, s mint ilyen, a nemzetközi jog egyik alapszabálya.

„Par in parem non habet iurisdictionem” - tartja a római elv (az egyenlőknek nincs hatalmuk/joghatóságuk egymás felett), és ennek megfelelően hosszú évszázadokon át az abszolút immunitás elve uralkodott az állam jogviszonyait illetően. Az államok egymás közötti kapcsolatainak két alapvető elve, a szuverén egyenlőség, illetve függetlenség doktrínái ugyanis útját állták annak, hogy egy adott állam bírósága egy külföldi állammal szemben - annak beleegyezése nélkül - eljárjon. ${ }^{42}$ A huszadik század során azonban az államok egyre gyakrabban váltak a nemzetközi magánjogi viszonyok alanyaivá, amely az immunitás tanát illetően is változást hozott: megszületett a funkcionális, más néven relatív immunitás elve. ${ }^{43}$ Eszerint

38 Érdekeik gyakran ütköznek a köz érdekével a művek hozzáférhetőségét illetően, valamint bizonyos esetben az államok visszaszolgáltatási igényeivel is.

${ }^{39}$ A perbeli legitimációjával összefüggésben érdemes felhívni a figyelmet a Bumper-ügyre, melyben az az angol fórumnak egy hindu templom, valamint egy benne fekvő kegytárgy eljárási képességéröl kellett döntenie. (Bumper Development Corporation v Commissioner of Police of the Metropolis and Others [1991] 1 WLR 1362, [1991] 4 All ER 638). Elemzi: Sandy GHAndHi - Jennifer James: „The God That Won” International Journal of Cultural Property 1992/2. 369-382 https://doi. org/10.1017/S0940739192000407. Részben ezzel a kérdéssel foglalkozott az amerikai fórum előtt zajló, nagy hatású Goldberg-ügy is, melyben egy ciprusi vallási társaság eljárási képességét vizsgálták. (Autocephalous Greek-Orthodox Church v. Goldberg and Feldman Fine Arts, Inc., 917 F.2d 278, 285 (7th Cir. 1990]) Elemzi: John Henry MERryman - Albert Edward: Law, Ethics, and the Visual Arts. Kluwer Law International (Alphen aan den Rijn: Kluwer Law International 2007) 252-263.; Meredith VAN PELT: „Autocephalous Greek Orthodox Church of Cyprus v. Goldberg and Feldman Fine Arts, Inc.: A Case for the Use of Civil Remedies in Effecting the Return of Stolen Art” Dickinson Journal of International Law 1990/3; Deidre L. CroweLL: „Autocephalous GreekOrthodox Church of Cyprus v. Goldberg \& Feldman Fine Arts, Inc.: Choice of Law in the Protection of Cultural Property” Texas International Law Journal 1992/1.

${ }^{40}$ Emily Behzadi: „Harmonizing the Law to Protect Cultural Diplomacy: The Foreign Cultural Exchange Jurisdictional Immunities Clarification Act" Journal of International Law and International Relations 2016. 13-14.

${ }^{41}$ BÁNRÉvy Gábor: A nemzetközi gazdasági kapcsolatok joga (Budapest: Szent István Társulat 2018) 61.

${ }^{42}$ Malcolm N. SHaw: Nemzetközi jog (Budapest: Osiris 2002) 431.

${ }^{43}$ Burián László - Raffai Katalin - Szabó Sarolta: Nemzetközi magánjog (Budapest, Pázmány Press 2017) 467. 
az állam, ha nem közhatalmi funkcióját gyakorolja, többé nem élvez mentességet. ${ }^{44}$ Az így kialakult relatív immunitást azóta számos jogforrásban deklarálták, ${ }^{45}$ azonban egyik dokumentumban sincsen kifejezett utalás a kulturális javak visszaszolgáltatásával kapcsolatos ügyekre. Ez annál is különösebb, mivel a nemzetek jellemzően egyetértenek a jogellenesen elvett, kisajátított mükincsek eredeti tulajdonosnak történő visszaszolgáltatására irányuló törekvésekkel. Teszik ezt többek között azért, mert az állam kulturális javaihoz történő kötődése nemzettudatot építő jelentőségű. ${ }^{46}$ Érzékelhető ez a nemzetközi egyezményekben testet öltő ígéretekkel, a központi nyilvántartások létrehozása által, a szigorú kiviteli szabályok beiktatásából, a diplomáciai és bírósági úton visszaszerzett mükincsek egyre növekvő számából. Másrészt a szuverenitás és a territorialitás elvei szerint minden államnak joga van teljes ellenőrzést gyakorolni a területén található erőforrások felett, tehát a nemzetközi jog is alapot ad hasonló tárgyú igényeiknek. ${ }^{47}$

${ }^{44}$ Az állam közjogi (jure imperii) jogviszonyait a jogviszony természete alapján szokás a magánjogi (jure gestionis) jogviszonyaitól elkülöníteni. A jogviszonyok jellegét illető határok azonban gyakran elmosódnak, s az állam felelősségre vonásának egyes problémái máig a tudományos diskurzus homlokterében áll. Lásd BuRián (50. lj.) 192.

${ }^{45}$ Ebben a körben kell említeni a nemzetközi szokásjogot írásba foglaló 2004-es ENSZ Egyezményt az államok és tulajdonuk joghatóság alóli mentességéről; az állami immunitásról szóló, Bázelben, az Európa Tanács égisze alatt 1972. május 16-án kelt európai egyezményt, valamint számos egyéb belső jogforrást - a common law országok jogrendjében például jellemzően található írott norma az állami immunitással kapcsolatban. Alessandro CHEcHI: „State Immunity, Property Rights, and Cultural Objects on Loan” International Journal of Cultural Property 2015/2-3. 285. https://doi. org/10.1017/S0940739115000211; Nout van WoudEnBERG: State Immunity and Cultural Objects on Loan (Boston: Martinus Nijhoff Publishers 2012) 107-108. https://doi.org/10.1163/9789004217027. Témánk szempontjából legfontosabb példa az egyesült királyságbeli 1978-as State Immunity Act, mely az abszolút immunitást funkcionálisba „fordító” bírói gyakorlat kodifikációjának tekinthető. BuRIÁN László - CzIGler Dezső Tamás - Kecskés László - VöRös Imre: Európai és magyar nemzetközi kollíziós magánjog (Budapest: Krim 2010) 167-168. A magyar szabályozást illetően, a Kódex szakított elődje megoldásával, és az immunitással kapcsolatos rendelkezéseket nem a joghatóság szabályai között tárgyalja. Az eljárásjogi részen belül a 34. fejezet foglalkozik a kérdéssel, mely így önálló eljárási előfeltételnek tekintendő. A törvény indokolása a szeparált elhelyezést az uniós joggal való összhang megteremtésén túl az állam mentességének alapvetően közjogi jellegével magyarázza. (T/14237. számú törvényjavaslat indokolással - a nemzetközi magánjogról. 84 . o.) Megjegyzendő, hogy egyes szerzők az állami immunitásra vonatkozó elkülönülő szabályozást tartanak szükségesnek, kiküszöbölendő az így létrejött, magánjogi és közjogi elemek keveredéséből eredeztetett dogmatikai hibákat. Lásd Gomвos (10. lj.) 93.

${ }^{46}$ Merryman klasszikus csoportosítása alapján az államok két csoportra bonthatók. Egyfelöl vannak a „forrás államok”, melyek alatt olyan mủkincsekben gazdag országokat értünk, mint Egyiptom, Görögország vagy India. Ezekben az államokban a műtárgyak száma messze túlmutat a „helyi felhasználáson”, tehát exportálásuk gazdasági szempontból észszerű lenne. Az országok másik csoportját a „piacállamok” képzik, ilyen Franciaország, Németország vagy az Egyesült Államok. Ezekben az államokban a kereslet meghaladja a kínálatot. A piacállamok ösztönöznék a szabad kereskedelmet, a megengedőbb kiviteli szabályok megalkotását. A forrásállamok azonban, kulturális örökségük részeként jelölve a tárgyakat, ódzkodnak a hasonló üzlettől. Ezt a jelenséget deklarálja a kulturális javak jogtalan behozatalának, kivitelének és tulajdona jogtalan átruházásának megakadályozását és megelőzését szolgáló eszközökről szóló 1970. évi UNESCO Egyezmény. John Henry MERRYMAN: „Two Ways of Thinking about Cultural Property” American Journal of International Law 1986/4. 832 .

47 Alessandro Chechi: The Settlement of International Cultural Heritage Disputes (Oxford: Oxford University Press 2014) 41., https://doi.org/10.1093/acprof:oso/9780198703990.001.0001. 
Egy, a világon egyedülálló jogszabályi rendelkezés ${ }^{48}$ és az annak nyomán kialakult bírói gyakorlat következtében a kulturális javak, különösen a kisajátított javak visszaszolgáltatását érintő jogviták évtizedek óta az Egyesült Államokban összpontosulnak. ${ }^{49} \mathrm{Az}$ állam perelhetőségének kérdésével kapcsolatos dilemmát a híres Altmann-ügyben ${ }^{50}$ így fogalmazta meg az amerikai fórum:

„A bíróság hosszú időn át a végrehajtó hatalomhoz utalta az állami immunitással kapcsolatban felmerült kérdéseket. Az 1952-es évig a vezérelv az volt, hogy a külföldi szuverénnek a mentességet minden esetben meg kell adni, a jó viszony fenntartása érdekében. Abban az évben a kormány elkezdte a »relatív immunitás elvét « alkalmazni, mely alapján a mentesség megilleti az államot szuverén vagy közhatalmi cselekedetei tekintetében, de magánjogi cselekedetei tekintetében nem. Bár ez a változás csekély hatással volt a szövetségi bíróságokra, mely helyzet zűrzavart okozott az állami immunitást érintő gyakorlatban: [...] a felelősség megoszlott két különböző hatalmi ág között. Ezen problémák kiküszöbölése érdekében az FSIA [Foreign Sovereign Immunities Act] kodifikálta a relatív immunitást, és az elsődleges felelősséget a bírósághoz utalta." 51

Megalkották tehát az FSIA-t, mely azért érdemel kiemelt figyelmet a restitúciós perek szempontjából, mert a más államokat alperesi pozícióba citáló perekkel kapcsolatos joghatósági szabályok kizárólagos forrását jelenti.

Szerkezetét tekintve a jogforrás először deklarálja a főszabályt, vagyis az államok USA bíróságainak joghatósága alóli immunitását, majd az ezt követő szakaszokban előbbi alól számos kivételt sorol. ${ }^{52}$ Ezek közül az 1605. § a) bekezdés (2),

48 Riccardo Pavoni: „Sovereign Immunity and the Enforcement of International Cultural Property Law" in Francesco Francioni - James Gordley (szerk.): Enforcing International Cultural Heritage Law (Oxford: Oxford University Press 2013) 86-87. https://doi.org/10.1093/acprof:oso/9780199680245.001.0001.

49 Lásd Roodt (27. lj.) 187.

${ }^{50}$ Republic of Austria v. Altmann, 541 U.S. 677 (2004).

${ }^{51}$ Az Altmann-ügy jelentős adalékot hozott az FSIA értelmezéséhez, mikor a bíróságnak törvény visszaható hatályáról kellett döntenie. Maria Altmann, osztrák-cseh származású örökösnő az egykoron családja tulajdonában álló Gustav Klimt-festmény visszaszolgáltatásáért indított eljárást az Egyesült Államokban, Ausztriával szemben. Ausztria a perben arra hivatkozott, hogy az FSIA az esetben nem alkalmazandó, ugyanis azt az Altmann által hivatkozott jogfosztás - melyre viszszaszolgáltatási igényét alapozta - előbb történt, minthogy a törvényt megalkották volna. Ennek következtében - érvel Ausztria - mentességet élvez a fórum eljárása alól. A fórum az FSIA megalkotásának célját figyelembe véve lefektette, hogy annak hatálya a korábban történt eseményekre is kiterjesztendő. SzABó Sarolta: „Állami immunitás és joghatóság a kisajátított műkincsekkel kapcsolatos amerikai perekben” Európai és Külföldi Jogi Szemle 2011/8. 490-491.

A másik, idő folyásával összefüggő eljárási akadályt, az elévülés kérdését is rendezni törekedett az amerikai törvényhozó. 2016-ban megszületett ugyanis a Holocaust Expropriated Art Recovery Act, amely egységesen hat évben határozza meg az elévülési időt a nácik által kisajátított mükincseket érintő, Egyesült Államokban folyó perekben, mely idő számítása a tárgy és a birtokosa hollétének felfedezésétől kezdődik. Jillian E. MEANEY: „From Platitudes to the Passage of the HEAR Act: How Procedural Obstacles in U. S. Courts Have Prevented the Restitution of Nazi-Expropriated Art and Congress's Efforts to Provide a Resolution" University of Florida Journal of Law and Public Policy 2017/2. 392-394.

52 A főszabály az FSIA 1604., a kivételek az FSIA 1605-1607. szakaszaiban találhatók. A legtöbb, állami immunitást érintő szabályozás - így a Kódex megfelelő passzusai is - hasonlóan a „kivételek technikájára" épül. 
a kisajátítás kivétele (expropriation exception) és (3) pontja, a kereskedelmi kivétel (commercial activity exception) emelendő ki, ugyanis a külföldi államokkal szemben zajló, kulturális javakkal kapcsolatos ügyekben jellemzően ezekre a kivételekre hivatkozva állapítják meg joghatóságukat az amerikai bíróságok. ${ }^{53}$

\subsection{AZ FSIA MÜKÖDÉSE - A DE CSEPEL-ÜGY}

Az FSIA-kivételek müködése kiválóan szemléltethető a nagy jelentőségű, magyar vonatkozású De Csepel-ügy bemutatásával, ${ }^{54}$ melyben az először magyar, majd egyesült államokbeli jogalkalmazónak kellett a Herzog-gyűjtemény sorsáról rendelkeznie.

A több mint százmillió dollárt érő kollekció a maga teljességében több mint kétezer-ötszáz műalkotásból állt, amelyet Herzog Mór Lipót báró és felesége állított össze. A második világháború évei alatt a zsidó származású Herzog család az üldöztetések elől külföldre menekült (Magyarországról az Egyesült Államokba, illetve Olaszországba), a gyűjtemény pedig szétszóródott - egyes, azóta fellelt darabjai magyarországi múzeumok, egyetemek birtokába kerültek, mások külföldön bukkantak fel. A Herzog-örökösök a kilencvenes évek elején tárgyalásokat kezdtek a magyar kormánnyal a gyüjtemény magyarországi darabjainak visszaszolgáltatása érdekében, melyek sikertelenségét követően az ügyet bírósági útra terelték. Az 1999-ben indított magyarországi eljárásban végül 2008-ban született jogerős ítélet, melyben a bíróság - amellett, hogy megállapította a magyar fórum kizárólagos joghatóságát az ügyre ${ }^{55}$ - elutasította az örökösök keresetét. ${ }^{56}$

A mütárgyak visszaszolgáltatását célzó eljárás 2010-ben az Egyesült Államokban folytatódott, amikor az amerikai és olasz örökösök benyújtották keresetüket a United States District Court for the District of Columbia előtt Magyarországgal, a Magyar Nemzeti Galériával, a Szépművészeti Múzeummal, az Iparművészeti Múzeummal, illetve a Budapesti Műszaki és Gazdaságtudományi Egyetemmel szemben. ${ }^{57} \mathrm{Az}$ amerikai eljárási szabályok alapján a külföldi állam eljárás alóli mentességét mindaddig vélelmezni kell, amíg a felperes nem bizonyítja az FSIA egyik kivételének fennállását.

53 Ezen exepciók széles körű alkalmazása erős vonzerőt jelent az USA fórumai részéről - annak 1976-os hatályba lépése óta több száz eljárás indult külföldi szuverénekkel szemben az Egyesült Államokban. Hannelore SkLAR: „Choice of Law under the Foreign Sovereign Immunities Act: Cassirer. Thyssen-Bornemisza Collection Foundation and the Unresolved Disagreement among the Circuits" Georgetown Journal of International Law 2015-2016. 1198.

${ }_{54}$ De Csepel v. Republic of Hungary, 859 F.3d 1094 (D.C. Cir. 2017), cert. denied (U. S. Jan. 7, 2019).

55 „[...] a kereset elbírálására a magyar bíróságnak van kizárólagos joghatósága, és a tulajdoni igény elbírálásakor a magyar jogot kell alkalmazni (a jelen perben alkalmazandó, nemzetközi magánjogról szóló 1979. évi 13. tvr. 55. § (1) bekezdés d) pont, 21. § (1) bekezdés, és 22. § (1) bekezdés)." Fővárosi Ítélőtábla 5.Pf.20.499/2006/33.

${ }^{56}$ SzABó Sarolta: „Államok, műkincsek és perek: A Herzog-gyűjtemény esete” in RAFFAI Katalin Szabó Sarolta (szerk.): Honeste benefacere pro scientia. Ünnepi kötet Burián László 65. születésnapja alkalmából (Budapest: Pázmány Press 2019) 279-280.

${ }^{57}$ De Csepel v. Republic of Hungary, 808 F. Supp. 2 d 113, 127 (D.D.C. 2011). 
Az örökösök a jogvita tárgyára tekintettel az FSIA kisajátítási kivételére - annak második mondatára - hivatkoztak.

Szükséges megjegyezni, hogy az FSIA által sorolt kivételek közül a restitúciós perekkel kapcsolatosan jelentősebb a kisajátítás kivétele, mely alapján „[a] külföldi állam nem mentes az Egyesült Államok és tagállamai bíróságainak joghatósága alól egy olyan ügyben sem, [...] amelyben a jogvita tárgya a nemzetközi jog megsértésével elvett vagyontárggyal kapcsolatos jog, és a vagyontárgy, illetve annak helyébe lépett bármely vagyon az Egyesült Államok területén tartózkodik a külföldi állam az Egyesült Államok területén kifejtett, ingóval kapcsolatos kereskedelmi tevékenysége révén; vagy a vagyontárgy, illetve annak helyébe lépett bármely vagyon egy olyan külföldi állam által müködtetett ügynökség vagy szervezet tulajdonában, illetve kezelésében áll, amely az Egyesült Államok területén kereskedelmi tevékenységet fejt ki [...].”

Az FSIA a „külföldi állam által az USA-ban kifejtett kereskedelmi tevékenység” kitételével kapcsolatban leszögezi, hogy az az USA-val való „jelentős kapcsolatot” takar. ${ }^{58}$ Elmondható, hogy ez a kereskedelmi tevékenység, ennek mennyisége és minősége határozza meg, hogy a külföldi állam „magánszereplőként” viselkedik-e a piacon, tehát kivonható-e az abszolút immunitás védelmi hálójából. ${ }^{59} \mathrm{Az}$ FSIA definíciója alapján akár szokásos üzleti magatartás, akár egy adott, egyedi ügylet vagy cselekedet is lehet. A kereskedelmi jelleg ugyanis az ügylet természete, és nem a célja alapján ítélendő meg. ${ }^{60}$ A kereskedelmi kapcsolat meglétét az ügyben a bíróság a többek között a múzeumok és az egyetem, valamint az Egyesült Államok közt lefolyt mütárgykölcsönzésekre alapította, továbbá arra a körülményre, hogy elöbbiek által kiadott angol nyelvű, a Herzog-gyűjteményből származó festményekkel illusztrált, amerikai látogatók számára értékesített útikönyveket árultak az amerikai

58 FSIA 1603. § (e).

${ }^{59}$ Érdemes ehhez kapcsolódva az EuB immunitással kapcsolatos legújabb döntésére kitekinteni. Az alapügy tényállása ugyan nem kulturális javakkal, hanem bizonyos biztosítási intézkedésekkel volt kapcsolatos, mégis alapot adott a Bíróságnak, hogy a Brüsszel I. bis rendelet 1. cikk (1) bekezdésében szereplő „polgári és kereskedelmi ügyek” és az acta iure imperii aktusok viszonyát értelmezze. ØE főtanácsnok a „polgári és kereskedelmi ügyek” meghatározását - annak elkülönítését attól az esettől, amikor a hatóság közhatalmat gyakorol - indítványában a következő három kritérium alapján javasolja: a felek között fennálló jogviszony, a kereset alapja, valamint a kereseti szabályok; mely kritériumokat együttesen kell megvizsgálni. A főtanácsnok álláspontja szerint „[...] végső soron az a meghatározó, hogy a kereset olyan jogon alapul, amely közhatalmi magatartásból vagy a közhatalom megnyilvánulásával jellemzett jogviszonyból ered.” A Bíróság döntésében követi a főtanácsnok érvelését. C-186/19 - Supreme Site Services és társai. Henrik Saugmandsgaard ØE főtanácsnok indítványa. 2020. április 2. ECLI:EU:C:2020:252. 84-85. pont; C-186/19 - Supreme Site Services és társai. A Bíróság ítélete. 2020. szeptember 3. ECLI:EU:C:2020:638.

${ }^{60}$ FSIA 1603. $§(d)$.

A kérdés - mint azt a bíróság a Weltover-ügyben [Republic of Argentina $v$. Weltover, Inc., 504 U. S. 607, 112 S.Ct. 2160, 119 L.Ed.2d 394 (1992)] részletezte -, nem az, hogy a külföldi állam a profit vagy valamely sajátosan szuverénre jellemző más cél elérése érdekében cselekszik-e, hanem az, hogy a külföldi állam által kifejtett tevékenység (függetlenül a mögöttes motívumtól) jellemzően olyan típusú-e, melyet a magánfelek fejtenek ki a kereskedelmi forgalomban. 
hitelkártyákat elfogadó múzeumi ajándékboltban. ${ }^{61} \mathrm{Az}$ egyetemet illetően a „jelentős" kapcsolat megállapítása azon alapult, hogy az részt vett hallgatói csereprogramokban és az Egyesült Államok Fulbright-programjában.

A kisajátítás kivételének első, illetve második mondatrésze közti viszonyt, mely szintén a kereskedelmi tevékenység követelményével kapcsolatos, a Chabadügyben ${ }^{62}$ tisztázta a bíróság. ${ }^{63} \mathrm{Ez}$ alapján érdemes kiemelni, hogy ha a peres fél külföldi állam, a vagyontárgy vagy az annak helyébe lépett vagyon jelenléte az USA-ban elengedhetetlen; ezzel szemben, ha külföldi állam által müködtetett ügynökség vagy szervezet a peres fél, ${ }^{64}$ az is elegendő, ha az ügynökség vagy szervezet az Egyesült Államok területén kereskedelmi tevékenységet fejt ki - a vagyontárgy jelenléte nem kitétel, ahogy az sem, hogy a szóban forgó vagyontárggyal kapcsolatban fejtse ki a tevékenységet. ${ }^{65,66}$ Ez pedig érzékelhetően tág teret hagy az amerikai fórum számára, hogy joghatóságát megállapítsa.

${ }^{61}$ De Csepel v. Republic of Hungary, 808 F. Supp. 2 d 113, 127 (D.D.C. 2011) 132.

${ }^{62}$ Agudas Chasidei Chabad of United States $v$. Russian Federation, et al. United States District Court, District of Columbia, 798 F. Supp. $2 d 260$ (D.D.C. 2011)

${ }^{63}$ Az ügy egy, a XVIII. században, Oroszországban alapított, New York-i zsidó vallási szervezet (Agudas Chasidei Chabad) és az Orosz Föderáció, valamint annak egy levéltára és könyvtára közt zajlott. A szervezet az ún. Schneerson-kollekció a második világháború évei alatt kisajátított, majd később oroszországi bírósági, valamint diplomáciai úton is sikertelenül követelt egyes darabjait kérte visszaszolgáltatni az Orosz Föderációtól és szervezeteitől. Az eljárás az amerikai bíróság előtt 2004-ben indult, és fő kérdése az FSIA 1605. § (a) (3) bekezdésének értelmezése, a külföldi szuverénnel szembeni joghatóság megállapíthatósága volt.

Az Orosz Föderáció védekezése több lábon állt, melynek egyike a kereskedelmi tevékenység kitételével volt kapcsolatos. Utóbbit illetően Oroszország kifejtette, hogy anomalikus lenne, ha a kisajátítási kivétel első mondatrésze által megkívánt „fizikai jelenlét” után a második, a külföldi állam ügynökségére vagy szervezetére utaló mondatrész sem a tárgy fizikai jelenlétét, de még az ügynökség vagy szervezet Egyesült Államok területén kifejtett tevékenysége és a fizikailag jelen lévő tárgy közti kapcsolatot sem kívánná meg. A bíróság azonban nem látott ilyen rendellenességet a kisajátítási kivétel ilyen kiterjesztő értelmezésében. A kivétel alkalmazását megalapozottnak találta, tekintettel a Levéltár és a Könyvtár (melyek az Orosz Föderáció által nem vitatottan „külföldi állam ügynökségének vagy szervezetének” minősülnek) Egyesült államokban folytatott tevékenységére (pl. kiadókkal kötött értékesítési szerződések, jutalékok és jogdíjak beszedése). A joghatóság 2008-as megállapítását követően az ügyben érdemi döntés 2010-ben született, amely elöírta a Schneerson-gyüjtemény visszaadását. Az Orosz Föderáció nyilatkozatában kijelentette, hogy tulajdonát illetően az amerikai bíróság joghatóságát nem ismeri el, annak döntését nem tekinti magára nézve kötelezőnek. A végrehajtás sikertelensége és ennek kapcsán a további jogi, illetve diplomáciai lépések kirobbantották az USA és Oroszország közt a „kulturális hidegháborút”, melynek hatásai napjainkig érződnek. SzABó Sarolta: „A kulturális javakkal kapcsolatos restitúciós perek és a külföldi állammal szembeni végrehajtás: a Chabad v. Orosz Föderáció ügy tanulságai” in FekETE Balázs - HoRvÁthy Balázs - Kreisz Brigitta (szerk.): A világ mi magunk vagyunk... Liber Amicorum Imre Vörös (Budapest: HVG-Orac 2014) 462-470.

${ }^{64} \mathrm{Az}$, hogy az államot mely állami szerv képviselje annak polgári jogi jogviszonyaiban, belső államjogi kérdés. Ennek meghatározása az állam szuverenitásának egyik megnyilvánulása. Lásd BuRIÁNCZIGLER-KeCsKÉS-VÖRÖS (45. lj.) 161.

${ }^{65}$ Luke TATTERSALL: „Derailing State Immunity: A Broad-Brush Approach to Jurisdiction under Claims for the Expropriation of Cultural Property” International Journal of Cultural Property 2019/2. 188. https://doi.org/10.1017/S0940739119000146.

${ }^{66}$ A vizsgált ügyben a múzeumok, illetve az egyetem a külföldi állam által müködtetett ügynökség, illetve szervezet kategóriájába esnek. 
A de Csepel-ügy felperesei, a kisajátítási kivétel megállapíthatatlansága esetére a kereskedelmi kivétel alkalmazását kérték. ${ }^{67} \mathrm{~A}$ kivétel, mely az FSIA kivételei közül a bírósági gyakorlatban leggyakrabban hivatkozott kitétel, ${ }^{68}$ a következőképpen hangzik: „[a] külföldi állam nem mentes az Egyesült Államok és tagállamai bíróságainak joghatósága alól egy olyan ügyben sem, [...] amelyben a kereset egy külföldi állam Egyesült Államokban kifejtett kereskedelmi tevékenységén; vagy a külföldi állam másutt folytatott kereskedelmi tevékenységével összefüggésben az Egyesült Államok területén kifejtett tevékenységén alapul; vagy a külföldi állam másutt folytatott kereskedelmi tevékenységével összefüggésben az Egyesült Államok területén kívül kifejtett tevékenységén alapul, mely azonban az Egyesült Államokban közvetlen hatást vált ki.” A kisajátítási kivétel alapján megállapított joghatóság mellett azonban az elsőfokú eljárásban nem volt szükség a kereskedelmi kivétel feltételeinek vizsgálatára. Nem így a fellebbviteli fórum ${ }^{69}$ eljárásában, mely más szemszögből közelítette meg az ügyet.

Álláspontja szerint a kereset nem a gyűjtemény első kisajátításával, hanem az alperes által későbbiekben - a visszaadás megtagadásával - megszegett letéti megállapodással kapcsolatos. ${ }^{70} \mathrm{~A}$ gyüjtemény második világháború utáni kezelésével ugyanis letéti jogviszony jött létre, s a felek minden további követelése tulajdonképpen ezzel függ össze.

A fórum értelmező munkájának középpontjában azon kérdések álltak, hogy vajon a letéti szerződés megszegése kereskedelmi tevékenységgel összefüggő cselekedet-e, illetve hogy az közvetlen hatást váltott-e ki az Egyesült Államokban. ${ }^{71} \mathrm{~A}$ „kereskedelmi tevékenységgel összefüggő cselekedetet” illetően a törvényi megfogalmazás tág mozgásteret hagyott a bíróságoknak. ${ }^{72} \mathrm{~A}$ Weltover-ügyben kifejlesztett tesztre figyelemmel a letéti szerződés megszegése a bíróság megítélése szerint olyan tevékenység, melyet a piac bármely magánszereplője elkövethetne; az aktusban a szuverén jelleg aligha nyilvánul meg. ${ }^{73} \mathrm{~A}$ „közvetlen hatás” kritériuma megkívánja, hogy az alperes, vizsgálat alá vont üggyel összefüggő bizonyos kötelezettségeinek teljesítési helye az Egyesült Államokban legyen. A döntés indokolásában az olvasható, hogy - habár a felperes erre kifejezetten nem hivatkozott -, a hatás megállapítható, hiszen a letéti szerződés alapján a mütárgyak visszaszolgáltatásának

${ }^{67}$ De Csepel v. Republic of Hungary, 808 F. Supp. $2 d$ 113, 127 (D.D.C. 2011) 126-128.

${ }^{68}$ David P. Stewart: The Foreign Sovereign Immunities Act: A Guide for Judges. Federal Judicial Center, 2013. 56. (fjc.gov/content/foreign-sovereign-immunities-act-guide-judges) 44.

${ }^{69}$ De Csepel v. Republic of Hungary, 714 F.3d 591, 593 (D.C. Cir. 2013).

70 A letét jogintézményének kulturális javakkal kapcsolatos ügyekben játszott kiemelt szerepéről lásd: Norman PALmer: „The Role of Bailment in Cultural Property Claims” Art Antiquity and Law 2014/3.

71 De Csepel v. Republic of Hungary, 714 F.3d 591, 593 (D. C. Cir. 2013) 599.

${ }^{72}$ Azok pedig hajlottak is a tág értelmezésre - bizonyos esetekben a mütárgy Egyesült Államokban történő kiállítása is megvalósította a kereskedelmi tevékenységgel összefüggő aktust. Lásd BEHZADI (40. lj.) 14-15.

73 A Malewicz-ügyben kifejtettek szerint „[h]a elnagyoltan szeretnénk megfogalmazni, a »kereskedelmi « és a »szuverén « kifejezések egyszerűen ellentétesek: ha egy cselekedet olyan, amelyet csak szuverén végezhet el, akkor az nem lehet »kereskedelmi «. Hasonlóképpen, ha egy cselekedet olyan, amelyet magánszemély végezhet, akkor az nem lehet »szuverén «." [Malewicz v. City of Amsterdam, 362 F. Supp. $2 d$ 298, 313 (D.D.C. 2005) 313.] 
helye (az alperes számára is nyilvánvaló módon) részben az amerikai felperes lakhelye volt. ${ }^{74}$

Az állam abszolút immunitását lerontó kivételek ilyen kiterjesztő értelmezése egy esetjogi tendenciának volt mondható, ${ }^{75}$ mely napjainkban módosulni látszik. Ennek megfelelően 2017-ben a United States District Court for the District of Columbia megismételt eljárásában a kisajátítás kivételét alkalmazva a múzeumokkal, illetve az egyetemmel ellentétben Magyarországgal mint alperessel szemben joghatósága hiányát állapította meg. ${ }^{76}$

\section{ZÁRSZÓ}

A restitúciós perek megindulását övező újdonságok, sajátosságok tehát a következőképp foglalhatók össze.

Az EU tagországaiban ugyan viszonylag kevés eljárás folyik, a tendencia azt mutatja, hogy idővel egyre több és több igénylő fog előállni. Az új bizonyítékok, a dokumentumok digitalizálásával és elérhetővé válásával egyre inkább hozzáférhetővé válnak, ${ }^{77}$ ezzel elősegítve a jogellenesen elvett mủalkotások eredetkutatását. ${ }^{78}$ Ezt felismerve dolgozik az Európai Unió a kulturális javak jelen állapotában fragmentált, így kevéssé hatékony védelmi rendszerének erősítésén. Egyes vélemények szerint az Unió feladata egy határokon átívelő hatáskörű koordináló hatóság létrehozása, mely megszünteti a kulturális javakkal kapcsolatos jogviták jelenlegi, eseti alapú, főként nemzeti jogon nyugvó kezelését." ${ }^{79}$ Ezzel szemben mások az egységes normák (lex culturalis) megalkotását irreális ábrándnak tartják csupán, s a jogalkotási pluralizmust tekintik reális kiindulási alapnak. ${ }^{80} \mathrm{Az}$ átfogó védelmi rend-

${ }^{74}$ De Csepel v. Republic of Hungary, 714 F.3d 591, 593 (D.C. Cir. 2013) 601.

${ }^{75}$ Lásd Tattersall (65. lj.) 184.

76 Lásd Szabó (56. lj.) 287-289.

Magyarországgal kapcsolatban a joghatóság elutasításának oka a kisajátítási kivétel kereskedelmi nexust megkövetelő tétele. Ez alapján ugyanis, ha a per alanya külföldi állam, követelmény a szóban forgó mütárgyak fizikai jelenléte az Egyesült Államok területén (ellenben a külföldi állam szervezetével vagy ügynökségeivel szemben indított eljárásokkal, melyeket a törvény szövege alapján kevésbé „erős” védelem illeti). [De Csepel v. Republic of Hung., 859 F.3d 1094, 1106 (D. C. Cir. 2017) 1106.]

77 A teljesség igénye nélkül: a legnagyobb privát adatbázis a The Art Loss Register (artloss.com), nonprofit szervezet az International Foundation for Art Research (ifar.org), az Interpol adatbázisa a Stolen Works of Art Database (https://www.interpol.int/Crimes/Cultural-heritage-crime/StolenWorks-of-Art-Database). Az FBI kereshető adatbázisa a National Stolen Art File (https://www. fbi.gov/investigate/violent-crime/art-theft/national-stolen-art-file); a Lost Art Database (https:// www.lostart.de/) és a lootedart.com kifejezetten a nácik által kisajátított műkincsekre specializálódott. Nyilvánosan kereshető a Miniszterelnökség Műtárgyfelügyeleti Hatósági Főosztály által vezetett nyilvántartás a mutargy.kormany.hu oldalon. Az elveszett orosz mükincsek az Orosz Föderáció Kulturális Minisztériumának holnapján böngészhetők (http://lostart.ru).

78 Lásd SALM (18. lj.) 8.

79 Willy C. E. H. DE CLERCQ: Report on a legal framework for free movement within the internal market of goods whose ownership is likely to be contested (2002/2114(INI))" (https://www.europarl. europa.eu/) 11.

${ }^{80}$ Lásd Roodt (27. lj.) 269. 
szer kialakításának módja a jövő talánya, az bizonyos azonban, hogy a Brüsszel I. bis rendelet által beiktatott különleges joghatósági ok nagy lépés a kulturális javak megóvásának terén, mely magyar viszonylatban szintén elmondható a Kódex megfeleltethető rendelkezéséről.

Míg Európában a jogalkotó igyekszik joghatóságot biztosítani az egyes - jogvita elbírálására alkalmasnak ítélt, de korábban hasonló felhatalmazottsággal nem rendelkező - bíróságoknak a kulturális javak visszaszolgáltatásáért folyó ügyekkel kapcsolatban, addig az USA-ban a bíróságok jogfejlesztő tevékenysége hat azonos irányba. A nemzetközi színtéren tapasztalható jelenség hátterében az az igény áll, hogy ezeket a sajátos jellegű jogvitákat ideálisabb körülmények közt bírálják el. Évtizedes tendenciaként figyelhető meg, hogy a megengedő jogszabályi környezet okán - különös figyelemmel arra a jelenségre, mely alapján az amerikai fórumok külföldi szuveréneket illetően is megállapítják eljárási képességüket - a visszaszolgáltatási perek az USA-ban összpontosulnak. A joghatósági szabályozás kiterjesztő értelmezésének jelensége azonban a legutóbbi döntések nyomán mérséklődni látszik, így megadva az esélyt a jelenleg megfigyelhető forum shopping fenomén visszaszorulásának és az európai jogalkotási eredmények erőteljesebb érvényesülésének. 